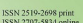

НАУКОВИЙ ВІСНИК

IB⿴囗十⺝

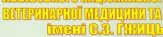

cientific mesenenger of Lviv National University of

and

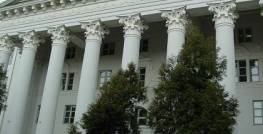

Том 23 № 94

2021
Науковий вісник Дьвівського національного університету ветеринарної медицини та біотехнологій імені С.3. Гжицыкого. Серія: Сільськогосподарські науки

\section{Scientific Messenger of Lviv National University} of Veterinary Medicine and Biotechnologies. Series: Agricultural sciences

https://nvlvet.com.ua/index.php/agriculture

UDC 636.2.082.355:637.115

\title{
Evaluation of first-born cows of different genotypes on the indicators of udder development and milk production
}

\author{
O. O. Borshch, O. V. Borshch \\ Bila Tserkva National Agrarian University, Bila Tserkva, Ukraine
}

Article info

Received 04.02.2021

Received in revised form 03.03 .2021

Accepted 04.03.2021

Bila Tserkva National Agrarian University, pl. 8/1 Soborna Bila Tserkva, 09117, Ukraine. Tel: +38-098-622-07-97 E-mail: borshcha@outlook.com
Borshch, O. O., \& Borshch, O. V. (2021). Evaluation of first-born cows of different genotypes on the indicators of udder development and milk production. Scientific Messenger of Lviv National University of Veterinary Medicine and Biotechnologies. Series: Agricultural sciences, 23(94), 36 41. doi: $10.32718 /$ nvlvet-a9407

Recently, an important element in improving the genetic traits of dairy cattle on commercial farms is the use of interbreeding (crossbreeding). The use of crossbreeding makes it possible to use a variety of additive genetic levels between breeds to grow individuals with higher economic potential. The aim of this study was to analyze the development of udder parameters in crossbred first-borns compared to purebred counterparts and to study the indicators of milk production during milking. The research was conducted on the first-born Ukrainian black-spotted dairy breed and first-generation crossbreeds obtained by crossing with the Brown Swiss breed and on the Ukrainian red-spotted dairy breed and first-generation crossbreeds obtained by crossing Ukrainian red-spotted dairy breed with Montbeliarde breed. Two groups of purebred and local first-borns were formed in both farms. Both farms use the same type of year-round feeding of cows with complete feed mixtures. The study was performed on first-born cows during weaning (2-3 months of lactation). It was found that local first-borns obtained by crossing red-spotted and Montbeliarde breeds outnumbered purebred red-spotted analogues in terms of measurements and udder indices. The opposite situation was observed in local first-borns obtained as result of crossing black-spotted and Brown Swiss breeds, which were inferior in these characteristics to purebred black-spotted analogues. In purebred black and red-spotted cows, the rates of single and daily milking were higher than in local ones. Also, purebred first-borns had a longer duration of single milking, indicators of average and maximum intensity of milk production and milk yield in the first 3 minutes. Prospects for further research are to study the productivity for completed lactation, the quality of milk and the duration of the service period.

Key words: cows, exterior, udder, crossbreeding, Brown Swiss and Montbeliarde breeds, measurements.

\section{Оцінка корів-первісток різних генотипів за показниками розвитку вимені та молоковиведення}

\author{
О. О. Борщ, О. В. Борщ
}

Білоцерківський національний аграрний університет, м. Біла Церква, Украӥна 
лактації). Встановлено, щзо помісні первістки, отримані в результаті схрешування червоно-рябих і монбельярдських порід, переважали чистопородних червоно-рябих аналогів за показниками промірів та індексів вимені. Протилежна ситуачія спостерігалась у помісних первісток, отриманих в результаті схрещування чорно-рябих і швіџьких порід, котрі поступались за даними ознаками чистопородним чорно-рябим аналогам. У чистопородних чорно- та червоно-рябих корів показники разового і добового надоїв були вищими, ніж у помісних. Також у чистопородних первісток була довщою тривалість разового доӥння, показники середньої та максимальної інтенсивності молоковиведення $і$ видоєність за перші 3 хвилини. Перспективи подальших досліджень полягають у вивчені продуктивності за закінчену лактацію, якісного складу молока та тривалості сервіс-періоду.

Ключові слова: корови, екстер 'єр, вим'я, кросбридинг, ивіиька і монбельярдська породи, проміри.

\section{Вступ}

Інтенсифікація молочного скотарства на основі промислової технології змінила вимоги до порід молочного напряму продуктивності (Berry et al., 2014). Молочна худоба, яка виведена для утримання на комплексах і фермах з інтенсивною промисловою технологією виробництва молока, має вирізнятися не лише високими надоями, доброю пристосованістю до машинного доїння на високопродуктивних установках, міцним здоров'ям і стійкістю до захворювань, а й бажаною формою вимені, котра характеризується сукупністю морфологічних ознак (Ruban et al., 2017; Borshch et al., 2020; Ruban et al., 2020). В процесі утворення молока бере участь весь організм тварини, проте специфічним органом, котрий продукує молоко і синтезує його складові частини, є молочні залози вим'я (Tetens et al., 2014; Shonka-Martin et al., 2019). Воно повинно бути великим за обсягом, пропорційно сформованим, ванно- або чашоподібної форми, добре розвиненим як в ширину, так і довжину, з поширенням частин далеко вперед по череву і назад за лінію стегна. Дно має бути розміщене на достатній відстані від землі, передня частина має щільно прилягати до черева, а задня - бути високо і міцно прикріплена 3 чітко вираженою глибокою борозною підтримуючої зв'язки. Дійки - розташовані посередині часток вимені на оптимальній відстані, циліндричної форми, бажаної довжини і товщини, спрямовані вертикально вниз. Морфологічні ознаки вимені $є$ найбільш важливими і надійними екстер'єрними показниками високої удійності і технологічності корів (Puppel et al., 2018; Borshch et al., 2019).

Процеси молоковиведення і молоковіддачі мають вагомий вплив на функціональну діяльність молочної залози і нерозривно пов'язані з молокотворним процесом. При правильному виконанні підготовчих операцій, котрі передують початку процесу молоко виведення, машинне доїння у корів викликає повноцінний рефлекс молоковіддачі та сприяє збільшенню їх продуктивності. До основних технологічних ознак, що характеризують придатність тварин до машинного доїння, належать: форма, розміри вимені та дійок, рівномірність розвитку часток (індекс вимені), тривалість та інтенсивність доїння, а також рівномірність видоювання окремих часток.

Останнім часом важливим елементом підвищення генетичних ознак молочної худоби на товарних фермах є застосування міжпородного схрещування (кросбридингу) (Heins \& Hansen, 2012; Heins et al., 2012; Malchiodi et al., 2014). Застосування кросбридингу дає можливість використовувати різноманітні адитивні генетичні рівні між породами для вирощування осо- бин 3 вищим економічним потенціалом. Також за рахунок прояву ефекту гетерозису кросбредні корови відзначаються вищими адаптаційними і стресостійкими ознаками порівняно з чистопородними аналогами (Borshch et al., 2018).

Метою досліджень було проаналізувати розвиток показників вимені у кросбредних первісток порівняно 3 чистопородними аналогами та вивчити показники молоковиведення у період роздоювання.

\section{Матеріал і методи досліджень}

Дослідження проводили у СТОВ ОП "Михайлів-

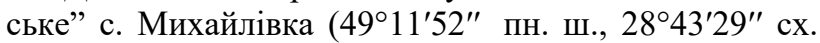
д.) Вінницького району Вінницької області на первістках української чорно-рябої молочної породи та помісях першого покоління, отриманих в результаті схрещування зі швіцькою породою, та у ТОВ “Азо-

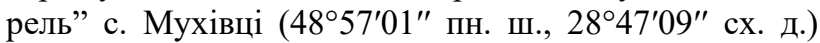
Немирівського району Вінницької області на телицях української червоно-рябої молочної породи й помісях першого покоління, отриманих у результаті схрещування української червоно-рябої молочної з монбельярдською породою. В обох господарствах було сформовано по дві групи чистопородних та помісних телиць-аналогів 3 чисельністю по 25 (СТОВ “Михайлівське” та по 20 (ТОВ “Азорель”) голів у кожній. В обох господарствах застосовується однотипна цілорічна годівля корів повнораціонними кормосумішами. Дослідження проводили на коровах-первістках у період роздою (2-3 місяць лактації).

Морфологічні ознаки вим'я корів-первісток оцінювали на 2-3 міс. лактації після отелення, за одну годину до доїння, шляхом огляду та вимірювання. У піддослідних тварин визначали такі проміри: обхват, ширина, довжина вимені, довжина передніх і задніх дійок, відстань від дна вимені до землі (рис. 1). Піддослідні тварини були без ознак атрофії часток вимені та 3 правильним (вертикальним) їх розміщенням.

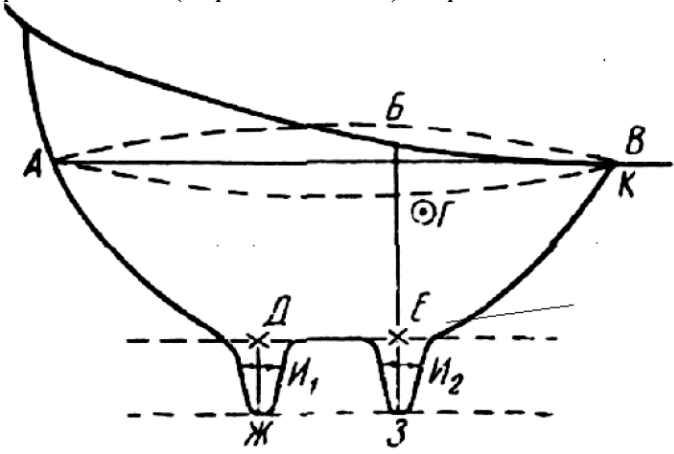

Рис. 1. Проміри вимені

АВ- обхват;

АК - довжина; 
Г- ширина;

Е3, ДЖ - довжина задньої та передньої дійки;

И1, И2 - діаметр передньої та задньої дійки.

Форму вимені визначали за співвідношенням його довжини і ширини. До ванноподібної форми зараховували за переваги його довжини над шириною на $15 \%$ і більше, чашоподібної - в межах 1-14. Умовну величину вимені обчислювали як добуток промірів його обхвату і глибини. Індекси формату, відносної величини і розміру вимені розраховували за методиками, запропонованими Polupan \& Koval, 2006.

\section{Результати та їх обговорення}

Найбажанішою формою вимені лактуючих тварин вважається ванно подібна - як найбільш продуктивна та технологічна. Встановлено, що у всіх групах тварин була перевага за ванноподібною формою вимені (табл. 1). Найвищий показник спостерігали у помісей чорно-рябої і швіцької порід - 81,24 \%, а найнижчий у помісей червоно-рябої породи 3 монбельярдською $72,37 \%$. Відсоток корів із чашоподібною формою вимені, котра також є притаманна коровам молочного типу, становив від 18,76 до 27,63.

\section{Таблиця 1}

Розподіл корів за формою вимені, \%

\begin{tabular}{ccccc}
\hline \multirow{2}{*}{ Форма вимені } & \multicolumn{4}{c}{ Порода, породність } \\
\cline { 2 - 5 } & $\begin{array}{c}\text { українська чорно- } \\
\text { ряба молочна }\end{array}$ & $\begin{array}{c}1 / 2 \text { української чорно-рябої } \\
\text { молочної та 1/2 швіцької }\end{array}$ & $\begin{array}{c}\text { українська червоно- } \\
\text { ряба молочна }\end{array}$ & $\begin{array}{c}1 / 2 \text { української червоно-рябої } \\
\text { молочної та } 1 / 2 \text { монбельярдської }\end{array}$ \\
\hline Ванноподібна & 78,17 & 81,24 & 73,58 & 72,37 \\
Чашоподібна & 21,83 & 18,76 & 26,42 & 27,63 \\
\hline
\end{tabular}

Чистопородні чорно-рябі первістки переважали помісних аналогів чорно-рябої із швіцькою породою за усіма основними промірами вимені (табл. 2). Зворотню ситуацію спостерігали в іншому дослідженні, де помісі червоно-рябої та монбельярдської порід переважали чистопородних червоно-рябих аналогів. Так, за основними промірами вимені: довжиною (на скільки воно далеко розташоване вперед на череві та виходить назад за кінцівками), шириною (вказують на потенціал вимені до високої спроможності секретувати та накопичувати молоко) та глибиною (характеризувати вим’я як цілісну секреторну та ємнісну систему) чистопородні чорно-рябі первістки переважали помісних на 3,62; 5,67 та 2,78 см відповідно. Водночас помісі червоно-рябої та монбельярдської порід переважали чистопородних червоно-рябих на: 2,93; 1,65 i 1,12 см. За технологічними вимогами вим'я корів повинно бути достатньо глибоким, що забезпечує його великий об' $€$, але не опускатися нижче скакального суглоба. Показник відстані від дна вимені до землі у чистопородних чорно-рябих первісток був на 1,45 см більшим, ніж у помісних аналогів, а у помісей червоно-рябої та монбельярдської порід - на 2,25 см порівняно 3 червоно-рябими аналогами. Інтенсивна технологія експлуатації корів вимагає чітких параметрів розвитку, розташування та форми дійок вимені. За показниками діаметра передніх та задніх дійок суттєвої різниці між групами не виявлено.

\section{Таблиця 2}

Проміри вимені корів-первісток, см (M \pm m)

\begin{tabular}{|c|c|c|c|c|}
\hline \multirow[b]{2}{*}{ Проміри вимені } & \multicolumn{4}{|c|}{ Порода, породність } \\
\hline & $\begin{array}{c}\text { українська чорно- } \\
\text { ряба молочна }\end{array}$ & $\begin{array}{l}\text { 1/2 української чорно-рябої } \\
\text { молочної та } 1 \frac{2}{2} \text { швіцької }\end{array}$ & $\begin{array}{c}\text { українська червоно- } \\
\text { ряба молочна }\end{array}$ & $\begin{array}{c}\text { 1/2 української червоно-рябої } \\
\text { молочної та } 1 / 2 \text { монбельярдської }\end{array}$ \\
\hline Довжина & $39,74 \pm 0,77$ & $36,12 \pm 0,82^{* *}$ & $34,36 \pm 0,59$ & $37,29 \pm 0,71^{* *}$ \\
\hline Ширина & $34,29 \pm 0,78$ & $28,62 \pm 0,68^{* * *}$ & $27,53 \pm 0,34$ & $29,18 \pm 0,41^{* *}$ \\
\hline Глибина & $26,51 \pm 0,24$ & $23,73 \pm 0,92^{* *}$ & $24,46 \pm 0,47$ & $25,38 \pm 0,19$ \\
\hline Обхват & $112,03 \pm 1,88$ & $107,25 \pm 2,16$ & $105,37 \pm 2,78$ & $109,16 \pm 3,27$ \\
\hline $\begin{array}{c}\text { Відстань: } \\
\text { - від дна вимені }\end{array}$ & & & & \\
\hline $\begin{array}{c}\text { до землі } \\
\text { - між передніми }\end{array}$ & $57,32 \pm 0,79$ & $55,87 \pm 0,93$ & $56,47 \pm 0,54$ & $58,72 \pm 0,83^{*}$ \\
\hline дійками & $14,92 \pm 0,54$ & $14,55 \pm 0,70$ & $13,58 \pm 0,22$ & $14,02 \pm 0,17$ \\
\hline - задніми & $9,89 \pm 0,38$ & $9,80 \pm 0,23$ & $9,47 \pm 0,11$ & $9,54 \pm 0,08$ \\
\hline - бічними & $12,71 \pm 0,34$ & $12,47 \pm 0,48$ & $11,79 \pm 0,32$ & $11,95 \pm 0,30$ \\
\hline Довжина дійок: & & & & \\
\hline - передніх & $7,47 \pm 0,22$ & $7,40 \pm 0,25$ & $7,21 \pm 0,12$ & $7,26 \pm 0,08$ \\
\hline - задніх & $5,86 \pm 0,34$ & $5,78 \pm 0,47$ & $5,63 \pm 0,25$ & $5,73 \pm 0,29$ \\
\hline Діаметр дійок: & & & & \\
\hline - передніх & $2,30 \pm 0,07$ & $2,25 \pm 0,04$ & $2,26 \pm 0,05$ & $2,28 \pm 0,06$ \\
\hline - задніх & $2,21 \pm 0,03$ & $2,20 \pm 0,03$ & $2,18 \pm 0,02$ & $2,22 \pm 0,03$ \\
\hline
\end{tabular}


Передні дійки у піддослідних первісток мали довжину в середньому від 7,21 до 7,47 см, а задні були дещо коротшими та мали показник на рівні 5,635,86 см 3 незначною перевагою у чистопородних чорно-рябих та помісей червоно-рябих 3 монбельярдською породою. Було встановлено, що ширше розташування передніх дійок мали чистопородні чорно-рябі тварини порівняно з помісями чорно-рябих і швіцьких первісток - на 0,37 см, а помісі червоно-рябих і монбельярдських корів переважали чистопородних аналогів - на 0,44 см. Розташування задніх дійок у піддо- слідних первісток було дещо зближеним порівняно 3 передніми і становило від 9,47 до 9,89 см.

Для подальшої характеристики пропорційності розвитку вимені корів різних генотипів нами на основі промірів були визначені індекси вимені (табл. 3). За даними показниками прослідковувалась подібна тенденція, як і у випадку з промірами вимені, тобто перевага чистопородних чорно-рябих корів над помісями чорно-рябих і швіцьких первісток та перевага помісей червоно-рябих і монбельярдських помісей над чистопородними червоно-рябими.

\section{Таблиця 3}

Індекси та інші показники розвитку вимені корів-первісток $(\mathrm{M} \pm \mathrm{m})$

\begin{tabular}{|c|c|c|c|c|}
\hline \multirow[b]{2}{*}{ Показник } & \multicolumn{4}{|c|}{ Порода, породність } \\
\hline & $\begin{array}{c}\text { українська чорно- } \\
\text { ряба молочна }\end{array}$ & $\begin{array}{l}\text { 1/2 української чорно- } \\
\text { рябої молочної та 1/2 } \\
\text { швіцької }\end{array}$ & $\begin{array}{l}\text { українська черво- } \\
\text { но-ряба молочна }\end{array}$ & $\begin{array}{c}\text { 1/2 української червоно- } \\
\text { рябої молочної та 1/2 } \\
\text { монбельярдської }\end{array}$ \\
\hline Індекс формату, \% & $23,67 \pm 0,26$ & $22,12 \pm 0,19^{* *}$ & $23,21 \pm 0,34$ & $23,25 \pm 0,37$ \\
\hline $\begin{array}{c}\text { Індекс відносної } \\
\text { величини, \% }\end{array}$ & $60,28 \pm 0,73$ & $59,51 \pm 0,67$ & $54,06 \pm 0,81$ & $55,04 \pm 0,88$ \\
\hline $\begin{array}{c}\text { Індекс відносного } \\
\text { розміру, } \%\end{array}$ & $13,65 \pm 0,15$ & $12,28 \pm 0,13^{* * *}$ & $11,96 \pm 0,18$ & $12,86 \pm 0,22^{* *}$ \\
\hline $\begin{array}{l}\text { Індекс умовної } \\
\text { величини, у. од. } \\
\text { Умовний об'єм }\end{array}$ & $2969,91 \pm 108,22$ & $2545,04 \pm 88,52^{* *}$ & $2577,35 \pm 73,59$ & $2770,48 \pm 86,23$ \\
\hline вимені, $\mathrm{cm}^{3}$ & $12757,35 \pm 288,72$ & $8672,87 \pm 211,48^{* * *}$ & $8160,72 \pm 203,82$ & $9752,92 \pm 253,17^{* * *}$ \\
\hline
\end{tabular}

В умовах промислової технології виробництва молока велике значення мають показники молоковиведення корів. Встановлено, що чистопородні первістки чорно- та червоно-рябої порід переважали помісних аналогів за показниками разового і добового надою на 0,81 i 1,94 та 0,28 і 0,79 кг відповідно (табл. 4). При цьому показники тривалості разового доїння у чистопородних чорно- та червоно-рябих порід переважали помісних аналогів на 0,26 та 0,10 хв відповідно. За показником середньої інтенсивності молоковиведення чистопородні первістки переважали помісей на 0,16 кг/хв (чорно-рябі) і на 0,04 кг/хв - червоно-рябі. Проте показник видоєності за перші 3 хв доїння у помісей чорно-рябої і швіцької порід був меншим на $3,68 \%$, а у помісей червоно-рябої і монбельярдської порід на - 1,40 \% порівняно з чистопородними аналогами. За показниками величини ручного додою та повноти видоювання суттєвої різниці між тваринами піддослідних груп не виявлено.

\section{Таблиця 4}

Показники молоковиведення корів-первісток $(\mathrm{M} \pm \mathrm{m})$

\begin{tabular}{|c|c|c|c|c|}
\hline \multirow[b]{2}{*}{ Показник } & \multicolumn{4}{|c|}{ Порода, породність } \\
\hline & $\begin{array}{c}\text { Українська } \\
\text { чорно-ряба } \\
\text { молочна }\end{array}$ & $\begin{array}{c}\text { 1/2 української } \\
\text { чорно-рябої молоч- } \\
\text { ної та 1/2 швіцької }\end{array}$ & $\begin{array}{c}\text { Українська } \\
\text { червоно-ряба } \\
\text { молочна }\end{array}$ & $\begin{array}{c}\text { 1/2 української червоно- } \\
\text { рябої молочної та 1/2 мон- } \\
\text { бельярдської }\end{array}$ \\
\hline Тривалість разового доїння, хв & $4,90 \pm 0,19$ & $4,64 \pm 0,24^{*}$ & $5,02 \pm 0,16$ & $4,92 \pm 0,12$ \\
\hline Разовий надій, кг & $8,73 \pm 0,42$ & $7,92 \pm 0,33$ & $8,37 \pm 0,25$ & $8,09 \pm 0,22$ \\
\hline $\begin{array}{l}\text { Добовий надій, кг } \\
\text { Інтенсивність }\end{array}$ & $20,28 \pm 0,76$ & $18,34 \pm 0,58^{*}$ & $19,24 \pm 0,52$ & $18,45 \pm 0,39$ \\
\hline молоковиведення, кг/хв: & & & & \\
\hline - максимальна & $2,71 \pm 0,23$ & $2,55 \pm 0,17$ & $2,59 \pm 0,24$ & $2,46 \pm 0,19$ \\
\hline - середня & $1,85 \pm 0,04$ & $1,83 \pm 0,09$ & $1,74 \pm 0,05$ & $1,70 \pm 0,05$ \\
\hline Видоєність за перші 3 хв д & & & & \\
\hline оїння, кг & $6,27 \pm 0,24$ & $5,98 \pm 0,37$ & $5,72 \pm 0,39$ & $5,48 \pm 0,28$ \\
\hline$\%$ & 71,82 & 75,50 & 66,33 & 67,73 \\
\hline Величина ручного додою, кг & 0,057 & 0,053 & 0,042 & 0,040 \\
\hline Повнота видоювання, \% & 99,35 & 99,33 & 99,50 & 99,51 \\
\hline
\end{tabular}

Примітка: ${ }^{*}-\mathrm{P} \geq 0,95$ порівняно з чистопородними чорно- та червоно-рябими породами 
Результати наших досліджень частково збігаються 3 результатами, отриманими у дослідженнях Kargo et al., 2021, котрі встановили, що показники параметрів вимені у помісних первісток голштинської і червоної датської порід були вищими порівняно з чистопородними голштинами. Подібні дані було отримано і в результатах досліджень Dezetter et al., 2017, котрі вказують на кращі ознаки вимені у кросбредних первісток, отриманих в результаті схрещування голштинів і монбельярдів та голштинів і червоних скандинавських корів, порівняно з чистопородними голштинськими аналогами. Також встановлено і зниження добової продуктивності у помісних первісток порівняно з чистопородними, що збігається з одержаними нами результатами (Bryant et al., 2007; Lembeye et al., 2016; Hazel et al., 2017; Clasen et al., 2019). В дослідженнях Clasen et al., 2020 вказано на вираженість ознак ванноподібного, тобто такого, що найбільш придатне до машинного доїння, вимені у помісних первісток швіцької породи порівняно $з$ чистопородними голштинськими аналогами.

\section{Висновки}

Встановлено, що помісні первістки, отримані в результаті схрещування червоно-рябої і монбельярдської порід, переважали чистопородних червоно-рябих аналогів за показниками промірів та індексів вимені. Протилежна ситуація спостерігалась у помісних первісток, отриманих в результаті схрещування чорнорябої і швіцької порід, котрі поступалися за вказаними ознаками чистопородним чорно-рябим аналогам. У чистопородних чорно- та червоно-рябих корів показники разового і добового надоїв були вищими, ніж у помісних. Також у чистопородних первісток була довшою тривалість разового доїння, більші показники середньої та максимальної інтенсивності молоковиведення і видоєності за перші 3 хвилини.

\section{References}

Berry, D. P., Wall, E., \& Pryce, J. E. (2014). Genetics and genomics of reproductive performance in dairy and beef cattle. Animal, 8(1), 105-121. doi: $10.1017 / \mathrm{S} 1751731114000743$.

Borshch, O. O., Gutyj, B. V., Sobolev, O. I., Borshch, O. V., Ruban, S. Yu., Bilkevich, V. V., Dutka, V. R., Chernenko, O. M., Zhelavskyi, M. M., \& Nahirniak, T. (2020). Adaptation strategy of different cow genotypes to the voluntary milking system. Ukrainian Journal of Ecology, 10(1), 145-150. doi: 10.15421/2020_23.

Borshch, A. A., Ruban, S., Borshch, A. V., \& Babenko, O. (2019). Effect of three bedding materials on the microclimate conditions, cows behavior and milk yield. Polish Journal of Natural Sciences, 34, 19-31. URL: http://rep.btsau.edu.ua/handle/BNAU/2091.

Borshch, A. A., Borshch, A. V., Lutsenko, M. M., Merzlov, S. V., Kosior, L. T., Lastovska, I. A., \& Pirova, L. V. (2018). Amino acid and mineral composition of milk from local Ukrainian cows and their crossbreedings with Brown Swiss and Montbeliarde breeds. Journal of the Indonesian Tropical Animal Agriculture, 43(3), 238-246. doi: 10.14710/jitaa.43.3.238-246

Bryant, J. R., López-Villalobos, N., Pryce, J. E., Holmes, C. W., Johnson, D. L., \& Garrick, D. J. (2007). Short communication: Effect of environment on the expression of breed and heterosis effects for production traits. Journal of Dairy Science, 90, 1548-1553. doi: 10.3168/jds.S0022-0302(07)71640-5.

Clasen, J. B., Fikse, W. F., Kargo, M., Rydhmer, L., Strandberg, E., \& Østergaard, S. (2020). Economic consequences of dairy crossbreeding in conventional and organic herds in Sweden. Journal of Dairy Science, 103, 514-528. doi: 10.3168/jds.2019-16958.

Clasen, J. B., Fogh, A., \& Kargo, M. (2019). Differences between performance of F1 crossbreds and Holsteins at different production levels. Journal of Dairy Science, 102, 436-441. doi: 10.3168/jds.2018-14975.

Dezetter, C., Bareille, N., Billon, D., Côrtes, C., Lechartier, C., \& Seegers, H. (2017). Changes in animal performance and profitability of Holstein dairy operations after introduction of crossbreeding with Montbéliarde, Normande, and Scandinavian Red. Journal of Dairy Science, 100(10), 8239-8264. doi: 10.3168/jds.201611436.

Hazel, A. R., Heins, B. J., \& Hansen, L. B. (2017). Fertility, survival, and conformation of Montbéliarde $\times$ Holstein and Viking Red $\times$ Holstein crossbred cows compared with pure Holstein cows during first lactation in 8 commercial dairy herds. Journal of Dairy Science, 100(11), 9447-9458. doi: 10.3168/jds.201712824.

Heins, B. J., Hansen, L. B., \& De Vries, A. (2012). Survival, lifetime production, and profitability of crossbreds of Holstein with Normande, Montbeliarde, and Scandinavian Red compared to pure Holstein cows. Journal of Dairy Science, 95(2), 1011-1021. doi: $10.3168 /$ jds.2011-4525.

Heins, B. J., \& Hansen, L. B. (2012). Short communication: Fertility, somatic cell score, and production of Normande x Holstein, Montbeliarde $\mathrm{x}$ Holstein, and Scandinavian Red x Holstein crossbreds versus pure Holsteins during their first 5 lactations. Journal of Dairy Science, 95(2), 918-924. doi: 10.3168/jds.2011-4523.

Kargo, M., Clasen, J.B., Nielsen, H.M., Byskov, K., \& Norberg, E. (2021). Short communication: Heterosis and breed effects for milk production and udder health traits in crosses between Danish Holstein, Danish Red, and Danish Jersey. Journal of Dairy Science, 104(1), 678-682. doi: 10.3168/jds.2019-17866.

Lembeye, F., López-Villalobos, N., Burke, J. L., \& Davis, S. R. (2016). Breed and heterosis effects for milk yield traits at different production levels, lactation number and milking frequencies. New Zealand Journal of Agriculture Research, 59, 156-164. doi: 10.1080/00288233.2016.1156551.

Malchiodi, F., Cecchinato, A., \& Bittante, G. (2014). Fertility traits of purebred Holsteins and 2- and 3breed crossbred heifers and cows obtained from Swedish Red, Montbéliarde, and Brown Swiss sires. Journal of Dairy Science, 97, 7916-7926. doi: $10.3168 /$ jds.2014-8156. 
Polupan, Yu. P., \& Koval, T. P. (2006). Morfologichni osoblivosi vim'ya koriv ukraiinskoii chervonoii molochnoii porodi. Visnik agrarnoii nauki, 1, 23-28 (in Ukrainian).

Puppel, K., Bogusz, E., Gołębiewski, M., Nałęcz-Tarwacka, T., Kuczyńska, B., Slósarz, J., Budziński, A., Solarczyk, P., Kunowska-Slósarz, M., \& Przysucha, T. (2018). Effect of Dairy Cow Crossbreeding on Selected Performance Traits and Quality of Milk in First Generation Crossbreds. Journal of Food Science, 83(1), 229-236. doi: 10.1111/1750-3841.13988.

Ruban, S. Yu., Borshch, O. V., \& Borshch, O. O. (2017). Suchasni tekhnolohiyi vyrobnytstva moloka. (osoblyvosti ekspluatatsiyi, tekhnolohichni rishennya, eskizni proekty) [Modern milk production technologies. (peculiarities of operation, technological decisions, sketch designs)]. Kharkiv: STYLIZDAT (in Ukrainian).
Ruban, S., Borshch, O. O., Borshch, O. V., Orischuk, O., Balatskiy, Y., Fedorchenko, M., Kachan, A., \& Zlochevskiy, M. (2020). The impact of high temperatures on respiration rate, breathing condition and productivity of dairy cows in different production systems. Animal Science Papers and Reports, 38(1), 61-72.

Shonka-Martin, B. N., Heins, B. J., \& Hansen, L. B. (2019). Three-breed rotational crossbreds of Montbéliarde, Viking Red, and Holstein compared with Holstein cows for feed efficiency, income over feed cost, and residual feed intake. Journal of Dairy Science, 102(4), 3661-3673. doi: 10.3168/jds.201815682.

Tetens, J., Thaller, G., \& Krattenmacher, N. (2014). Genetic and genomic dissection of dry matter intake at different lactation stages in primiparous Holstein cows. Journal of Dairy Science, 97, 520-531. doi: $10.3168 /$ jds.2013-7301. 